\title{
molecules
}

ISSN 1420-3049

www.mdpi.com/journal/molecules

Article

\section{Caloxanthones O and P: Two New Prenylated Xanthones from Calophyllum inophyllum}

Hao-Fu Dai ${ }^{1,2}$, Yan-Bo Zeng ${ }^{1,2}$, Qi Xiao ${ }^{1}$, Zhuang Han ${ }^{1}$, You-Xing Zhao ${ }^{3}$, Wen-Li Mei ${ }^{1,2, *}$

1 Key Laboratory of Tropical Crop Biotechnology, Ministry of Agriculture, Institute of Tropical Bioscience and Biotechnology, Chinese Academy of Tropical Agricultural Sciences, Haikou 571101, Hainan, China; E-Mails: hfdai2001@yahoo.com.cn (H-F.D.); zengyanbo@163.com (Y-B.Z.); qixiao78wm@163.com (Q.X.); hanzone@yahoo.cn (Z.H.)

2 International Joint Laboratory for Research and Development of Tropical Medicinal Plants, Chinese Academy of Tropical Agricultural Sciences, Haikou 571101, China

3 State Key Laboratory of Phytochemistry and Plant Resources in West China, Kunming Institute of Botany, Chinese Academy of Sciences, Kunming 650204, Yunnan, China; E-Mail: xyzhao@mail.kab.ac.cn (Y-X.Z.)

* Author to whom correspondence should be addressed; E-Mail: meiwenli@yahoo.com.cn.

Received: 30 November 2009; in revised form: 4 January 2010 / Accepted: 8 January 2010 / Published: 27 January 2010

\begin{abstract}
Chemical investigation of the EtOH extract of the twigs of Calophyllum inophyllum collected in Hainan Province of China resulted in the isolation of two new prenylated xanthones, caloxanthone $\mathrm{O}$ (1) and caloxanthone P (2). Their structures were elucidated by a study of their physical and spectral data. Compound $\mathbf{1}$ exhibited cytotoxicity against human gastric cancer cell line (SGC-7901), with an $\mathrm{IC}_{50}$ value of $22.4 \mu \mathrm{g} \mathrm{mL}^{-1}$.
\end{abstract}

Keywords: Calophyllum inophyllum; caloxanthone O; caloxanthone P; cytotoxic activity; prenylated xanthones 


\section{Introduction}

Calophyllum inophyllum Linn, which belongs to the family Clusiaceae, is an evergreen shrub widely distributed in tropical areas. It is used in traditional Chinese folk medicine for the treatment of eye diseases, wounds, rheumatism and inflammations [1,2]. The chemical literature reflects the existence of wide variety of natural products in this plant, such as pyranocoumarins [3-9], xanthones [4,5,8], triterpenes [9,10], and flavonoids [11], which possessed various bioactivities such as anti-HIV-1 [3], anti-microbial [9], and cytotoxic activities [9,12]. Previously, we isolated a new cytotoxic prenylated xanthone from the twigs of $C$. inophyllum collected in Hainan Province of China [12]. In the continuous search for bioactive constituents, two new prenylated xanthones, named caloxanthones $\mathrm{O}(\mathbf{1})$ and $\mathrm{P}$ (2) were obtained. Compound $\mathbf{1}$ exhibited cytotoxicity against human gastric cancer cell line. The present paper discusses their structural elucidation and cytotoxicity.

\section{Results and Discussion}

Compound 1, was obtained as a yellow powder that reacted positively to the Gibbs and $\mathrm{FeCl}_{3}$ reagent, indicating the presence of phenolic groups. Its HR-ESI-MS spectrum showed the quasimolecular $[\mathrm{M}+\mathrm{Na}]^{+}$ion peak at $\mathrm{m} / \mathrm{z} 467.1681$ (calc. 467.1676), corresponding to the molecular formula $\mathrm{C}_{24} \mathrm{H}_{28} \mathrm{O}_{8}$. This formula could also be validated through its ${ }^{1} \mathrm{H}-\mathrm{NMR},{ }^{13} \mathrm{C}-\mathrm{NMR}$ and DEPT data. The IR spectrum displayed free hydroxyl $\left(3,560 \mathrm{~cm}^{-1}\right)$, chelated hydroxyl $\left(3,160 \mathrm{~cm}^{-1}\right)$, conjugated carbonyl $\left(1684 \mathrm{~cm}^{-1}\right)$, and aromatic ring $\left(1,589,1,540 \mathrm{~cm}^{-1}\right)$ absorptions. These data, together with those obtained from the UV spectrum $\left[\lambda_{\max }(\mathrm{MeOH}) 217,222,252,282,321 \mathrm{~nm}\right]$ were consistent with the presence of a xanthone skeleton $[4,5]$. In the ${ }^{1} \mathrm{H}-\mathrm{NMR}$ spectrum, a chelated hydroxyl group $\delta_{\mathrm{H}}$ $13.73(\mathrm{~s}, 1 \mathrm{H})$, two isolated aromatic protons $\delta_{\mathrm{H}} 6.19(\mathrm{~s}, 1 \mathrm{H}), 6.78(\mathrm{~s}, 1 \mathrm{H})$ and one methoxyl $\left(\delta_{\mathrm{H}} 3.84\right)$ were observed. The ${ }^{1} \mathrm{H}-\mathrm{NMR}$ spectrum of 1 also showed two methyl singlets $\left(\delta_{\mathrm{H}} 1.25\right.$ and $\left.\delta_{\mathrm{H}} 1.55\right)$, a methyl doublet $\left(\delta_{\mathrm{H}} 1.36, J=6.5 \mathrm{~Hz}\right)$ and one-proton quartet $\left(\delta_{\mathrm{H}} 4.56, J=6.2 \mathrm{~Hz}\right)$, which suggested the presence of an $\alpha, \alpha, \beta$-trimethyldihydrofuran ring [4]. Furthermore, two methyl singlets $\left(\delta_{\mathrm{H}} 1.15, \delta_{\mathrm{H}}\right.$ $1.17)$, an oxymethine proton $\left(\delta_{\mathrm{H}} 3.41,1 \mathrm{H}, \mathrm{dd}, J=6.3,9.6 \mathrm{~Hz}\right)$, and two methylene protons $\left(\delta_{\mathrm{H}} 2.62\right.$ and 3.78 , each $1 \mathrm{H}$ ) were observed in the ${ }^{1} \mathrm{H}-\mathrm{NMR}$ spectrum, which indicated the presence of a $\mathrm{C}_{5}$ unit characterized as a 2,3-dihydroxy-3-methylbutyl chain in $\mathbf{1}$ [13]. Assignment of the ${ }^{13} \mathrm{C}$-NMR spectral data are shown in Table 1. A combination of the ${ }^{1} \mathrm{H}-{ }^{1} \mathrm{H}$ COSY and HMQC experiments permitted the assignment of all the protonated carbons. It remained to establish the positions of the substituents on the xanthone skeleton. In the HMBC spectrum (Figure 2), the proton of chelated hydroxyl group 1-OH $\left(\delta_{\mathrm{H}} 13.73\right)$ was correlated to three carbons C-9a $\left(\delta_{\mathrm{C}} 102.7\right), \mathrm{C}-2\left(\delta_{\mathrm{C}} 92.9\right)$, and C-1 $\left(\delta_{\mathrm{C}} 163.5\right)$, which suggested that the chelated hydroxyl group was located at $\mathrm{C}-1$. Aromatic carbons with an oxygen function were observed at C-1 $\left(\delta_{\mathrm{C}} 163.5\right), \mathrm{C}-3\left(\delta_{\mathrm{C}} 164.9\right)$ and $\mathrm{C}-4 \mathrm{a}\left(\delta_{\mathrm{C}} 151.3\right)$ in the ${ }^{13} \mathrm{C}-\mathrm{NMR}$ spectrum, which indicated that this aromatic ring was a phloroglucinol ring [14]. Therefore, the $\alpha, \alpha, \beta-$ trimethyldihydrofuran ring was clearly fused at C-4 through an oxygen at C-3 position. This result was further confirmed by the long-range correlations of $\mathrm{H}-12\left(\delta_{\mathrm{H}} 1.25\right)$ and $\mathrm{H}-13\left(\delta_{\mathrm{H}} 1.55\right)$ with $\mathrm{C}-4\left(\delta_{\mathrm{C}}\right.$ $112.0)$ and $\mathrm{H}-14\left(\delta_{\mathrm{H}} 4.56\right)$ with $\mathrm{C}-3\left(\delta_{\mathrm{C}} 164.9\right)$ in the HMBC spectrum. The positions of the 2,3-dihydroxy-3-methylbutyl chain and the remaining phenolic hydroxyl group were established as follows. In the $\mathrm{HMBC}$ spectrum (Figure 2), the methylene protons $\mathrm{H}_{2}-16\left(\delta_{\mathrm{H}} 3.78\right.$ and $\left.\delta_{\mathrm{H}} 2.62\right)$ were correlated to three aromatic carbons C-8a $\left(\delta_{\mathrm{C}} 110.8\right), \mathrm{C}-7\left(\delta_{\mathrm{C}} 117.7\right)$, and C-8 $\left(\delta_{\mathrm{C}} 139.4\right)$. The latter 
resonance at C-8 also gave cross-peak with the oxymethine proton $\mathrm{H}-17$ ( $\left.\delta_{\mathrm{H}} 3.41\right)$. These results demonstrated clearly that the 2,3-dihydroxy-3-methylbutyl moiety was located at C-8. The cross-peaks from the aromatic proton $\left(\delta_{\mathrm{H}} 6.78\right)$ to $\mathrm{C}-16\left(\delta_{\mathrm{C}} 36.7\right), \mathrm{C}-8 \mathrm{a}\left(\delta_{\mathrm{C}} 110.8\right)$, and $\mathrm{C}-5\left(\delta_{\mathrm{C}} 132.8\right)$ in the HMBC spectrum indicated that the aromatic proton $\left(\delta_{\mathrm{H}} 6.78\right)$ was assigned at $\mathrm{C}-7$ position. The methoxyl group was deduced to be located at C-5 position by ROESY experiment revealing the crosspeak from the 5-OMe $\left(\delta_{\mathrm{H}} 3.84\right)$ to $\mathrm{H}-13\left(\delta_{\mathrm{H}} 1.55\right)$ (Figure 2$)$. The downfield shifts of C-6 $\left(\delta_{\mathrm{C}} 155.3\right)$ and $\mathrm{C}-18\left(\delta_{\mathrm{C}} 71.9\right)$ revealed that each carbon should be connected to a hydroxyl group. The configuration at $\mathrm{C}-17$ has not been determined in this study because the amount of compound $\mathbf{1}$ is too low. On the basis of the above results, the structure of compound $\mathbf{1}$ was thus elucidated and named caloxanthone $\mathrm{O}$.

Figure 1. Structures of compounds 1 and 2.<smiles>COc1c(O)cc(C[C+](C)C(C)(O)O)c2c(=O)c3c(O)cc4c(c3oc12)C(C)(C)[C@H](C)O4</smiles>

1<smiles>C=C(C)C(O)Cc1cc(O)c(OC)c2oc3c4c(cc(O)c3c(=O)c12)O[C@H](C)C4(C)C</smiles>

2

Figure 2. Key HMBC and ROESY correlations of compounds 1 and 2.
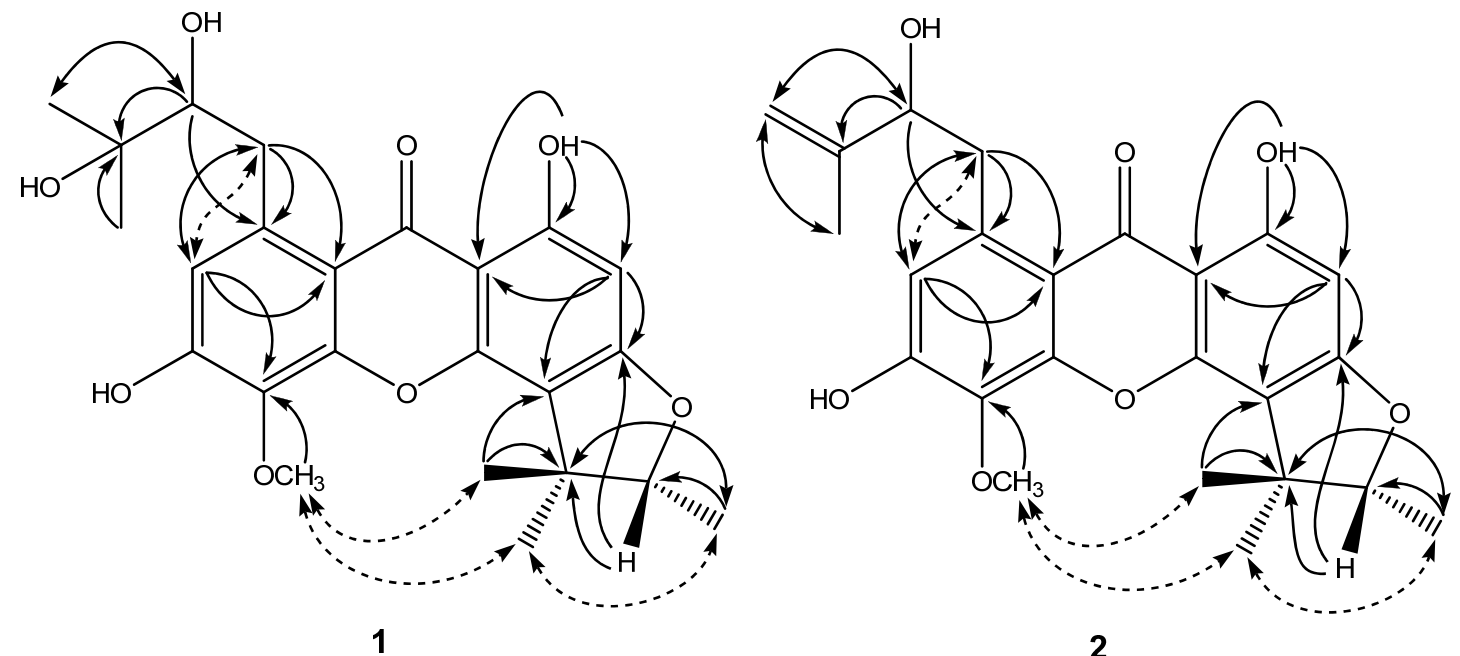

2 
Compound 2, was obtained as yellow powder and reacted positively to the Gibbs and $\mathrm{FeCl}_{3}$ reagent. The $[\mathrm{M}+\mathrm{Na}]^{+}$at $\mathrm{m} / z 449.1576$ in the HR-ESI-MS spectrum corresponds to the molecular formula $\mathrm{C}_{24} \mathrm{H}_{26} \mathrm{O}_{7}$ (calc. 449.1571). The IR and UV spectra were suggestive of a xanthone derivative. The ${ }^{1} \mathrm{H}-$ and ${ }^{13} \mathrm{C}$-NMR were closely related to those of $\mathbf{1}$, except for the substitution of $\mathrm{C}_{5}$ unit side chain in ring A. The ${ }^{1} \mathrm{H}-\mathrm{NMR}$ spectrum of 2 showed a methyl singlet $\left(\delta_{\mathrm{H}} 1.86\right)$, an olefinic methylene $\left(\delta_{\mathrm{H}} 4.77\right.$ and 4.96 , each $1 \mathrm{H})$, an oxymethine $\left(\delta_{\mathrm{H}} 4.35, \mathrm{dd}, J=8.8,3.6 \mathrm{~Hz}\right)$ and a methylene $\left(\delta_{\mathrm{H}} 3.02, \mathrm{dd}\right.$, $J=12.6,3.6 \mathrm{~Hz}$ and $\delta_{\mathrm{H}} 3.76, \mathrm{dd}, J=12.6,3.6 \mathrm{~Hz}$ ), which established a 2-hydroxy-3-methylbut-3-enyl group. The positions of the substitutions in 2 were established by HMBC and ROESY spectra (Figure 2). The configuration at C-17 has not been determined in this study because the amount of compound 2 is too low. From the above evidence, the structure of the compound $\mathbf{2}$ was thus confirmed, and given the trivial name caloxanthone $\mathrm{P}$.

Table 1. ${ }^{1} \mathrm{H}$ - and ${ }^{13} \mathrm{C}-\mathrm{NMR}$ data of 1 and 2. $\left({ }^{1} \mathrm{H}\right.$ at 400 and ${ }^{13} \mathrm{C}$ at $100 \mathrm{MHz} ; J$ in $\left.\mathrm{Hz}\right)$.

\begin{tabular}{|c|c|c|c|c|}
\hline \multirow[t]{2}{*}{ No. } & \multicolumn{2}{|r|}{$1^{\mathrm{a}}$} & \multicolumn{2}{|r|}{$2^{b}$} \\
\hline & $\delta_{C}$ & $\delta_{\mathrm{H}}$ & $\delta_{C}$ & $\delta_{\mathrm{H}}$ \\
\hline 1 & $163.5(s)$ & & $166.5(s)$ & \\
\hline 2 & $92.9(d)$ & $6.19(1 \mathrm{H}, s)$ & $95.1(d)$ & $6.13(1 \mathrm{H}, s)$ \\
\hline 3 & $164.9(s)$ & & $167.7(s)$ & \\
\hline 4 & $112.0(s)$ & & $114.1(s)$ & \\
\hline 5 & $132.8(s)$ & & $135.4(s)$ & \\
\hline 6 & $155.3(s)$ & & $153.8(s)$ & \\
\hline 7 & $117.7(d)$ & $6.78(1 \mathrm{H}, s)$ & $119.5(d)$ & $6.83(1 \mathrm{H}, s)$ \\
\hline 8 & $139.4(s)$ & & $140.6(s)$ & \\
\hline 9 & $181.5(s)$ & & $184.2(s)$ & \\
\hline $4 a$ & $151.3(s)$ & & $153.9(s)$ & \\
\hline $8 \mathrm{a}$ & $110.8(s)$ & & $113.8(s)$ & \\
\hline $9 a$ & $102.7(s)$ & & $105.3(s)$ & \\
\hline $10 \mathrm{a}$ & $151.3(s)$ & & $156.8(s)$ & \\
\hline 11 & $43.0(\mathrm{~s})$ & & $45.5(s)$ & \\
\hline 12 & $21.1(q)$ & $1.25(3 \mathrm{H}, s)$ & $22.7(q)$ & $1.33(3 \mathrm{H}, s)$ \\
\hline 13 & $25.0(q)$ & $1.55(3 \mathrm{H}, s)$ & $26.9(q)$ & $1.63(3 \mathrm{H}, s)$ \\
\hline 14 & $90.3(d)$ & $4.56(1 \mathrm{H}, q, 6.2 \mathrm{~Hz})$ & $92.6(d)$ & $4.57(1 \mathrm{H}, q, 6.5 \mathrm{~Hz})$ \\
\hline 15 & $13.9(q)$ & $1.36(3 \mathrm{H}, d, 6.5 \mathrm{~Hz})$ & $15.5(q)$ & $1.41(3 \mathrm{H}, d, 6.6 \mathrm{~Hz})$ \\
\hline \multirow[t]{2}{*}{16} & $36.7(t)$ & $3.78(1 \mathrm{H}, d, 12.8 \mathrm{~Hz}, \mathrm{H}-16 \mathrm{a})$ & $43.5(t)$ & $3.76(1 \mathrm{H}, d d, 12.6,3.6 \mathrm{~Hz}, \mathrm{H}-16 \mathrm{a})$ \\
\hline & & $2.62(1 \mathrm{H}, t, 11.3 \mathrm{~Hz}, \mathrm{H}-16 \mathrm{~b})$ & & $3.02(1 \mathrm{H}, d d, 12.6,3.6 \mathrm{~Hz}, \mathrm{H}-16 \mathrm{~b})$ \\
\hline 17 & $77.2(d)$ & $3.41(1 \mathrm{H}, d d, 9.6,6.3 \mathrm{~Hz})$ & $77.0(d)$ & $4.35(1 \mathrm{H}, d d, 3.6,8.8 \mathrm{~Hz})$ \\
\hline 18 & $71.9(s)$ & & $150.6(s)$ & \\
\hline \multirow[t]{2}{*}{19} & $25.5(q)$ & $1.15(3 \mathrm{H}, s)$ & $111.0(t)$ & $4.96(1 \mathrm{H}, s, \mathrm{H}-19 \mathrm{a})$ \\
\hline & & & & $4.77(1 \mathrm{H}, s, \mathrm{H}-19 \mathrm{~b})$ \\
\hline 20 & $25.7(q)$ & $1.17(3 \mathrm{H}, s)$ & $19.6(q)$ & $1.86(3 \mathrm{H}, s)$ \\
\hline $\mathrm{OMe}-5$ & $60.7(q)$ & $3.84(3 \mathrm{H}, s)$ & $62.8(q)$ & $3.96(3 \mathrm{H}, s)$ \\
\hline $\mathrm{OH}-1$ & & $13.73(1 \mathrm{H}, s)$ & & $13.68(1 \mathrm{H}, s)$ \\
\hline
\end{tabular}

${ }^{\mathrm{a}}$ In DMSO- $d_{6} \cdot{ }^{\mathrm{b}}$ In acetone- $d_{6}$. 
Compounds 1 and $\mathbf{2}$ were evaluated for their cytotoxic activity against human gastric cancer cell line (SGC-7901) using the MTT method. Compound 1 showed cytotoxic activity against the SGC-7901 cell line with the $\mathrm{IC}_{50}$ value of $22.4 \mu \mathrm{g} \mathrm{mL}^{-1}$, while compound 2 was inactive $\left(\mathrm{IC}_{50}>100 \mu \mathrm{g} \mathrm{mL}^{-1}\right)$.

\section{Experimental}

\section{General}

Melting points were obtained on a Beijing Taike X-5 stage apparatus and are uncorrected. Optical rotation was recorded using a Rudolph Autopol III polarimeter (Rudolph Research Analytical, NJ, USA). The UV spectra were measured on a Shimadzu UV-2550 spectrometer. The IR spectra were obtained on a Nicolet 380 FT-IR instrument, as $\mathrm{KBr}$ pellets. The NMR spectra were recorded on a Bruker AV-400 spectrometer, using TMS as an internal standard. The HRESIMS spectra were measured with an API QSTAR Pulsar mass spectrometer. Column chromatography was performed with silica gel (Marine Chemical Industry Factory, Qingdao, China) and Sephadex LH-20 (Merck). TLC was preformed with silica gel GF254 (Marine Chemical Industry Factory, Qingdao, China).

\section{Plant Material}

The twigs of Calophyllum inophyllum L. were collected in Wenchang county, Hainan Province, China in May 2006, the plant was identified by Associate Professor Zheng-Fu Dai of the Institute of Tropical Bioscience and Biotechnology, Chinese Academy of Tropical Agricultural Sciences, where a voucher specimen (No. 20060508) of C. inophyllum was deposited.

\section{Extraction and Isolation}

The dried and crushed twigs of C. inophyllum (19.9 kg) were extracted with $95 \% \mathrm{EtOH}(70 \mathrm{~L})$ three times at room temperature. After removal of EtOH by evaporation, the EtOH extract was suspended in water $(6.0 \mathrm{~L})$ and successively partitioned with petroleum ether $(4 \mathrm{~L})$ three times to give a Petrosoluble extract (290.0 g) and an aqueous residue. The Petro-soluble extract (290.0 g) was applied to a silica gel (200-300 mesh) column packed in $\mathrm{CHCl}_{3}$. The column was then eluted in gradient elution with $\mathrm{CHCl}_{3}$-acetone $(1: 0,20: 1,10: 1,5: 1,2: 1,0: 1)$ to afford 16 fractions. The active fraction (fraction $16,44.0 \mathrm{~g}$ ) was then subjected to repeated column chromatography over silica gel using Pet-EtOAc as eluent and further separated by column chromatography over Sephadex LH-20 using 95\% EtOH as eluent to afford $1(5.6 \mathrm{mg})$. The $95 \% \mathrm{MeOH}$ fraction $(245.0 \mathrm{~g})$ was subjected to vacuum liquid chromatography (VLC) over silica gel, eluting with gradient elution $\mathrm{CHCl}_{3}-\mathrm{MeOH}$ to afford 10 fractions. The active fraction (fraction 3, $5.7 \mathrm{~g}$ ) was then subjected to repeated column chromatography over silica gel using Pet-acetone as eluent and further separated by column chromatography over Sephadex LH-20 using 95\% EtOH as eluent to afford 2 (6.2 mg).

Caloxanthone O: Yellow powder, M.p. $228-230^{\circ} \mathrm{C} .[\alpha]_{\mathrm{D}}^{25}=+32.0(c=0.50, \mathrm{MeOH}) . \mathrm{UV}(\mathrm{MeOH})$ : $\lambda_{\max }\left(\log \varepsilon_{\max }\right): 217(1.25), 222(\mathrm{sh}), 252$ (0.51), $282(0.32), 321(0.28) \mathrm{nm}$. IR (KBr): $v=3560,3160$, 2314, 1684, 1589, 1540, 1419, 1384, $843 \mathrm{~cm}^{-1}$. HRMS ((+)-ESI): $m / z=467.1681$ (calcd. 467.1676 for $\left.\mathrm{C}_{24} \mathrm{H}_{28} \mathrm{O}_{8} \mathrm{Na},[\mathrm{M}+\mathrm{Na}]^{+}\right) .{ }^{1} \mathrm{H}$ and ${ }^{13} \mathrm{C}-\mathrm{NMR}$ : see Table 1. 
Caloxanthone P: Yellow powder, M.p. $203-204{ }^{\circ} \mathrm{C} .[\alpha]_{\mathrm{D}}^{25}=+56.0(c=0.50, \mathrm{MeOH})$. UV (MeOH): $\lambda_{\max }\left(\log \varepsilon_{\max }\right): 219$ (1.95), 258 (2.17), 281 (1.36), 325 (1.47) nm. IR (KBr): $v=3556,3473,3414$, 2414, 2230, 1725, 1619, 1585, 1343, 1276, 1048, 907, 861, $830 \mathrm{~cm}^{-1}$. HRMS ((+)-ESI): $m / z=449.1576$ (calcd. 449.1571 for $\left.\mathrm{C}_{24} \mathrm{H}_{26} \mathrm{O}_{7} \mathrm{Na},[\mathrm{M}+\mathrm{Na}]^{+}\right) .{ }^{1} \mathrm{H}$ and ${ }^{13} \mathrm{C}-\mathrm{NMR}$ : see Table 1 .

\section{Bioassay}

The 3-(4,5-dimethylthiazol-2-yl)-2,5-diphenyltetrazolium bromide (MTT) assay was performed according to the previously reported method [15]. The inhibition rates (IR\%) were calculated using OD mean values from $\mathrm{IR} \%=\left(\mathrm{OD}_{\text {control }}-\mathrm{OD}_{\text {sample }}\right) / \mathrm{OD}_{\text {control }}$. The $\mathrm{IC}_{50}$ value, which was defined as the concentration of sample needed to reduce $50 \%$ of absorbance relative to the vehicle-treated control, was determined using the Bliss method. The same experiment was repeated independently three times to obtain a mean $\mathrm{IC}_{50}$ and its standard deviation.

\section{Conclusions}

It was reported that a wide variety of bioactive natural products exist in the plant Calophyllum inophyllum, such as pyranocoumarins, triterpenes, and flavonoids, together with xanthones, especially prenylated xanthones. In our continuous search for bioactive constituents, two new prenylated xanthones, named caloxanthones $\mathrm{O}$ (1) and P (2) were obtained. Compound 1 showed cytotoxic activity against the SGC-7901 cell line with the $\mathrm{IC}_{50}$ value of $22.4 \mu \mathrm{g} \mathrm{mL} \mathrm{L}^{-1}$, while compound 2 was inactive $\left(\mathrm{IC}_{50}>100 \mu \mathrm{g} \mathrm{mL} \mathrm{m}^{-1}\right)$.

\section{Acknowledgements}

This research was financially supported by National Nonprofit Institute Research Grant of CATASITBB (ITBBZD0742) and National Programs for Science and Technology Development of China (2007BAI27B04).

\section{References}

1. Chen, H.Y. Flora of Hainanica; Science Press: Beijing, China, 1965; Volume 2, p. 56.

2. Dai, H.F.; Mei, W.L. Modern Research on Medicinal Plants in Hainan; China Science and Technology Press: Beijing, China, 2007; p. 31.

3. Patil, A.D.; Freyer, A.J.; Eggleston, D.S.; Haltiwanger, R.C.; Bean, M.F.; Taylor, P.B.; Caranfa, M.J.; Breen, A.L.; Bartus, H.R.; Johnson, R.K.; Hertzberg, R.P.; Westley, J.W. The inophyllums, novel inhibitors of HIV-1 reverse transcriptase isolated from the Malaysian tree, Calophyllum inophyllum Linn. J. Med. Chem. 1993, 36, 4131-4138.

4. Iinuma, M.; Tosa, H.; Tanaka, T.; Yonemori, S. Two xanthones from root bark of Calophyllum inophyllum. Phytochemistry 1994, 35, 527-532.

5. Iinuma, M.; Tosa, H.; Tanaka, T.; Yonemori, S. Two xanthones from roots of Calophyllum inophyllum. Phytochemistry 1995, 38, 725-728. 
6. Spino, C.; Dodier, M.; Sotheeswaran, S. Anti-HIV coumarins from calophyllum seed oil. Bioorg. Med. Chem. Lett. 1998, 8, 3475-3478.

7. Itoigawa, M.; Ito, C.; Tan, H.T.W.; Kuchide, M.; Tokuda, H.; Nishino, H.; Furukawa, H. Cancer chemopreventive agents, 4-phenylcoumarins from Calophyllum inophyllum. Cancer Lett. 2001, $169,15-19$.

8. Wu, Y.; Zhang, P.C.; Chen, R.Y.; Yu, D.Q.; Liang, X.T. Two new xanthones from Calophyllum inophyllum. Acta. Chim. Sinica 2003, 61, 1047-1051.

9. Yimdjo, M.C.; Azebaze, A.G.; Nkengfack, A.E.; Meyre, A.M.; Bodo, B.; Fomum, Z.T. Antimicrobial and cytotoxic agents from Calophyllum inophyllum. Phytochemistry 2004, 65, 2789-2795.

10. Govindachari, T.R.; Viswanathan, N.; Pai, B.R.; Rao, U.R.; Srinivasan, M. Triterpenes of calophyllum inophyllum linn. Tetrahedron 1967, 23, 1901-1910.

11. Li, Y.Z.; Li, L.Z.; Hua, H.M.; Li, Z.G.; Liu, M.S. Studies on flavonoids from stems and leaves of Calophyllum inophyllum. J. Chin. Materia Medica 2007, 32, 692-694.

12. Xiao, Q.; Zeng, Y.B.; Mei, W.L.; Zhao, Y.X.; Deng, Y.Y.; Dai, H.F. Cytotoxic prenylated xanthones from Calophyllum inophyllum. J. Asian Nat. Prod. 2008, 10, 993-997.

13. Iinuma, M.; Tosa, H.; Toriyama, N.; Tanaka, T.; Ito, T.; Chelladurai, V. Six xanthones from Calophyllum austroindicum. Phytochemistry 1996, 43, 681-685.

14. Iinuma, M.; Ito, T.; Miyake, R.; Tosa, H.; Tanaka, T.; Chelladurai, V. A xanthone from Garcinia cambogia. Phytochemistry 1998, 47, 1169-1170.

15. Mosmann, T. Rapid colorimetric assay for cellular growth and survival: Application to proliferation and cytotoxicity assays. J. Immunol. Method. 1983, 65, 55-63.

Sample Availability: Samples of the compound $\mathbf{1}$ and $\mathbf{2}$ are available from the authors.

(C) 2010 by the authors; licensee Molecular Diversity Preservation International, Basel, Switzerland. This article is an open-access article distributed under the terms and conditions of the Creative Commons Attribution license (http://creativecommons.org/licenses/by/3.0/). 